\title{
Social worker intervention performance in work with unemployed adults
}

\author{
Natalja Dmitrijeva and Ilvija Razgale \\ Rīga Stradiņš University, Latvia
}

\begin{abstract}
This article is based on the survey of scientific articles and results of practical research in effectiveness of social worker's intervention in work with adults having employment problems in Social service office of Riga. Research in effectiveness of social worker's intervention is important and topical issue nowadays, especially because there is no data on current practice in social service. The research revealed that there are no common methods for following up the work with adults having employment problems. Assessment of effectiveness of social worker's intervention is particularly aimed at intervention process and its results, such as planned and actual ones. Whereas effectiveness of social worker's intervention is determined by various factors, for example, social worker's and client's relations, support from colleagues etc. Feedback between managers and social workers plays a very important role in case of questions about practice. Author of this article analyses this and other factors that impact effectiveness of social worker's intervention.
\end{abstract}

Key words: social work, intervention performance, performance indicators, assessment, adults with employment problems.

\section{Introduction}

The conception of the work performance plays a significant role in the assessment of effectiveness and quality in social work, in the process of improving the organizational work, as well in social policy. "Professional Social Work Development Guidelines for 2014-2020" state that there are no clearly defined criteria for an adequate workload and the performance indicators for social work practice within the social service, as well as there is no monitoring and evaluation system in social work practice, etc. [7]. Intervention performance criteria and indicators are extremely significant not only for overcoming the lack of high-rank professionals, and in single cases also the basic competences, but also in developing positive motivation for professional activity [17]. The study of effectiveness of social worker's intervention reveals both the strengths and weaknesses and creates possibilities for their decrease and prevention.

During the assessment of intervention performance one can recognize the so-called "critical points" which play a decisive role in influencing the work quality and effectiveness. Turning attention to these points, the head of the organization and the staff can make essential positive changes, thus saving strength, time and resources. To define the intervention performance is, certainly, not an easy task, since the outcome of the work itself not always is unequivocal. Still, the assessment of the intervention performance can help change the assumptions into well-understandable facts, and to show the way to the improvement in one's practice $[10,12]$. Therefore, the conception of the intervention performance should be paid 
attention to in order to contribute to the improvements in the practical activities with clients and to stimulate the advancement of the profession.

Performance in social work is viewed as the possible maximum satisfaction of clients' social needs according to the conditions. In difference from effectiveness, performance does not evaluate the resource consumption, being important for achieving the result, but is targeted at the very social work process and its outcome, the assessment of the achievement of objectives. The idea of social work intervention performance is directed at the records of operational impact, referring to changes of client situations. Performance can be either expected (planned) or the really achieved [16].

The conception of work performance is indispensably related to the outcome indicators. In the social sphere, the following types of the work outcome are distinguished: maintenance, changes and the process/routine [6]. According to the views of social workers on social work outcome and their description they deal with:

- Social workers' professional views and understanding of work outcome in the context of the case management;

- The social worker's self-assessment of his/her activities;

- Client's point of view on the course of problem solution and the improvements, i.e., the outcome achieved thanks to a social worker's professionalism;

- Public expectations as to the would-be social work outcome;

- The institution's management views on what the performance is, and how to measure/evaluate the work outcome [4].

The actual target group in social work, where the issue of work performance is especially important, comprises adults with employment problems.

Promotion of employment is one of the basic ways in reduction of social exclusion [5], which favourably affects both the client, and his/her social system, and also renders a favourable impact on the country as a whole:

- when people encounter problems which they themselves cannot overcome (sometimes one can solve the problem only by means of social worker's assistance);

- when people, encountering the problems, cannot solve them on their own due to the lack of knowledge and resources;

- when people's lifestyle and behaviour are contradicting the legislation, when they cause serious risks, threaten their own and other people's welfare;

- when people seek help [2].

In social work with adults there may be the following results/outcomes: implementation/ training of the choice and control; economic welfare; improvement of the quality of one's life; developing of positive participation; health improvement [2].

Assessment of performance of social services and social workers' activities gives a possibility to find out which of the factors has a decisive role in attaining a certain result, and which factors are insignificant. Similarly, it is important to take into account the fact, that the assessment of performance is directed not only at the analysis of the achieved, but also at the very intervention/rendering of social service process [12].

There are no formulae of a universal social work, as well as social worker's intervention performance assessment, because either the services, or institutions, or the workers themselves are different. It is possible to form only methodological assessment approaches, which set the general principles and the logic of activity. Planning of assessment, determination of parameters and their assessment type have to be carried out for each case individually [12]. 
The assessment of activities of social service staff, however, can be done, basing on the following aspects: productivity; professional classification; successful rendering of individual services to each client; social worker's motivation to achieve the aims; correctness of the documentation; one's position in the team [12]. In addition, L. Porter and E. Lawler state: "Performance of a worker's input depends on his/her efforts, characteristic features and opportunities, as well as the assessment of one's own role" [15].

In order to assess the quality and performance of social services, it is possible to use the documentation analysis method, social cartography, population/clients' surveys and experts' questionnaires. By doing the assessment, one has to consider the amount of social services rendered and the resources available, the average time spent on solution of problem situations [11].

The assessment of performance of services predominantly includes quality parameters, which characterize the dynamics of the client's social-psychological condition. The evaluation of such condition can be performed by using questionnaires, tests and interviews. The assessment of a social worker's intervention performance can be done basing on such methods as comparison, monitoring, parametric method, direct assessment, social diagnostics, and self-assessment method. The intervention performance can be assessed in two phases: the first phase, in which the social worker, together with a client, defines the problem and finds out why the client has turned up for help, while the second phase can include the assessment of the factors influencing the client's problem situation. The assessment system of a client's internal and external strengths and weaknesses is applied too $[8,9,12,16]$.

It is also possible to use the following methods of quantitative and qualitative social worker's intervention and social work practice assessment: quantitative methods (singlesystem/single subject design), investigation methods of the clients' satisfaction, the study of quantitative data (documentation); qualitative methods (partially structured interviews with clients and colleagues, focus group discussions with clients, supervision, qualitative data (documentation study); and various other methods, for example, the secondary data analysis [1].

Criteria of social workers' intervention performance are varied. Among them, we can distinguish quantitative and qualitative criteria, and also objectives-norms, conditions-norms and boundaries-norms $[13,14]$. Thus, the assessment of performance of social workers' intervention is becoming more objective, since being done, relying on work situation and conditions.

Performance of social workers' activities is determined basing on general and specific criteria. The general criteria serve for the assessment of effectiveness / performance as the whole, while specific ones - for the basic social service assessment and the assessment of methods and forms of social work with different client groups. As the general criteria for social worker's effectiveness (performance) of practical work the social standards and regulations serve [13], in comparison to which the outcomes of the objectives achieved are assessed.

Social work specialist's activity is evaluated in relation to the following criteria: the ability to precisely define the client's problem, the ability to assess oneself and others adequately, the readiness to create and maintain the work environment and the atmosphere, as well as the improvement of the clients' quality of life [11, 13].

The general criteria of social workers' effectiveness (performance) are as follows:

- readiness and ability to solve work problems on their own initiation;

- ability to adapt to the new work place, fast adapt to organizational changes;

- readiness to work qualitatively under limited time conditions; 
- ability to recognize and overcome manifestations of aggressiveness and hostility in work with people, to reduce their anger;

- ability to respect the client's point of view;

- ability to work creatively, to act in a non-standard way and to find non-standard solutions;

- ability to work in the team, to render support to the colleagues;

- healthy ambitions, ability to set sufficiently high aims, to be critical to one's work; to recognize other staff achievements;

- interest to work in a definite institution, the presence of perspective objectives [13].

I. Majackaja (И.Н. Маяцкая) considers that the general service rendering process can be evaluated as qualitative and effective as well, if the activity has a clearly defined objective; it is based on the antidiscrimination approach; it is regularly controlled and analyzed; the activity is flexible to adapt to individual client's needs; it is important to clients, it favourably influences their socially-economic situation and behaviour; it focuses on preventive events; it does not cause the clients' dissatisfaction with the activity conditions [14].

As a result, in the social worker's intervention performance, working with unemployed adults and their problems, such indicators as the achievement of a fixed target, reaching of fixed short-term targets, increase of clients' motivation in solving the problems, recognition of individual client's own problems, etc. can be applied The indicators of social work performance can also be: the number of clients, clarity of clients' and social workers' rights and obligations in rendering of social services, focus on the outcome, respect of the client's point of view, professional social workers' burn-out intensity and the dynamics of the staff changes, access of qualitative information on social services and the order of their reception, etc. [16].

Social workers' intervention is a complex process and, possibly, apart from the planned work outcome there may arise the unexpected one, either positive or negative. In addition, a lot of contextual and situation factors affect the conditions of how easy or hard it is to achieve the social work objectives. For instance, clients' health and relationship with other people, habitation and its accessibility, employment, etc. influence the social work practice outcome $[3,6]$.

In individual cases, despite one's strivings, social work performance is not achieved. The reasons are as follows: imperfections in technical work for the accomodation of the place which slows down the work rate; lack of motivation among clients, or "inadequate clients" who do not want to cooperate, etc.; inter-institutional communications and coordination failures/imperfections [12]. The most complicated aspect for provision of the work quality is the fact, that it has to satisfy the interests of all the involved partners on condition, that the interests of the parties are sometimes quite antipodal.

The assessment of performance is the assessment of changes. Unfortunately, no instruments have been invented yet, by means of which we could clearly determine or measure the changes occurring with the people.

The process of the assessment of work performance and quality is encumbered by several factors, among them also the fact that the tangible result is not always seen at once, at times it is exposed only after a considerable period of time [12].

\section{Aim of research}

The research was aimed at finding out, what points to the performance of social workers' intervention in their work with adults with employment problems. 


\section{Material and methods}

The research was carried out at the territorial centers of Riga Social Service in October and November, 2016. In order to investigate the research topic more in detail, the analysis of the closed clients' cases was done, as well as partially structured interviews were undertaken with social workers, engaged in work with the mentioned clients' target group, and with the experts on the basic issues of the research, and the results acquired during the research and their analysis.

The research continues developing the before-carried out study on determining the relationship between a casework social worker' load and performance in work with the case idea.

\section{Results of research}

According to the acquired research results, performance of a social worker's intervention is determined by the factors related to social workers' professionalism and personality and as well as to clients. Among them, there is the interest of both parties to solve the problems, and also the social worker's skills to motivate the client, and the client's motivation level and its dynamics, and organizational and institutional factors as well. Social workers are of the opinion, that a significant condition for a successful intervention is the staff's consolidation, mutual support and organized co-visions, as well as a client's motivation to solve his/her problems.

In the opinions of social workers and experts in relation to performance of social workers' intervention in work with adults with employment problems, there exist slight differences. The research cleared out, that there is not a unified methodology, which would guide how to work with adults with the employment problems and it refers to both the intervention process and its assessment.

Experts came to the consensus that the assessment of performance of a social worker's intervention working with adults with the employment problems faces a series of difficulties. Among them, we can mention the unclearly defined social work practice boundaries, the possibility of the acquired data generalization, difficulties in determining the assessment criteria, etc., whereas only some social workers agree to such a statement.

It was stated, that between social workers and the management there exists an insufficient feedback on the assessment of social workers' intervention and their usefulness in the improvement of service quality. Though, by analyzing the case studies, one can determine the tendencies, the most topical problems, general summaries of social workers' work, as well it is possible to reveal the groundlessness of the accepted decisions.

The mean age of clients is 51 years. In general, it shows that people who become clients of social workers are prevalently pre-retirement age persons, for whom the age may cause serious difficulties in searching for the employment.

The client cases are closed due to various reasons. Mainly they are connected to finding a hired job, disability settlement and client involvement into hired temporary public work. A significant reason for the client case closure is the fact, that the client does not cooperate and/or lose his/her status of the unemployed. In cases of the client's non-participation, the social worker becomes powerless, since he/she cannot force the client to participate. Most commonly the client's problems are multiple.

\section{Discussion}

It might be worth depicting the short-term objectives and the dynamics to attain them in the client's documentation, since not in all cases the long-term objectives are attained, while the 
short-term objectives are. It would be useful as to the reviewing or investigating the case, as well as to the assessment of the social worker's intervention performance.

Solution of the existing problems has to be performed at all levels: micro, meso and macro. The changes in the order of receiving social assistance, ensuring the clients to have possibilities to increase their quality of life, making the support base, as well as providing services corresponding to the client's problems, thus decreasing social workers' helplessness in different cases in their practice.

It is necessary to increase the social workers' understanding for the need of the intervention assessment, as well as to involve social workers in the development / improvement of the performance assessment instrument.

In accordance with the analysis of scientific literature and the acquired research data, the assessment of social workers' intervention working with adult unemployed persons can use both social workers and clients (direct assessment method) surveys - interviews, discussions. Being one of the most effective types of assessment of a social worker's practice, one can work out a special survey. In the assessment of performance of social workers' intervention one can integrate the assessment and achievement management system of clients' internal and external strengths and weakness, as well as study both qualitatively, and quantitatively the clients' case documentation, and on the basis of them develop proposals and reveal visible work imperfections.

\section{Conclusions}

1. In social work it is important to develop, to specify and to make the assessment and improvement system of professional work outcome.

2. The assessment of a social worker's intervention performance is a time-consuming and quite a complicated process, because the performance criteria of a social worker's intervention are complex - they comprise both quantitative and qualitative indicators. These indicators, in their turn, deal with both the standard and norm system, and with the depiction of the clients' social status, which requires the assessment and analysis of several factors.

3. The assessment of performance of intervention can be either primary, or a regular one, which envisages the investigation and comparison of the situation dynamics. Since the assessment includes a subjective aspect, in the assessment of performance of several social workers' intervention in work with adult persons it is necessary to use different assessment methods as much as possible for the increase of the objectivity of the results of the research methods.

\section{References}

[1] M. Alston, W. Bowles, Research for Social Workers: An introduction to methods, 2nd edn. (Allen \& Unwin, 2003), p. 188-189

[2] D. Brand, T. Reith, D. Statham, The Need for Social Work Intervention, 18, 50, http://www.gov.scot/Resource/Doc/47121/0020810.pdf (2005)

[3] M. Kivipelto, S. Blomgren, P. Saikkonen, P. Karjalainen, Web Based Tool for Social Work Effectiveness Evaluation; Revista de Asistenţ $\backslash$ Social $\backslash$, anul XIV, 3; 20-21 (2015)

[4] I. Lāss, V. Roga, SD, Kāda ir sociālā darba mērvienūba? 3(36), 39 (2010)

[5] L.R. Labklājīibas ministrija, Bezdarba un sociālās atstumtības iemesli un ilgums $\mathbf{6 3}$ (2007), www.lm.gov.lv/upload/esf/bezdarba_iemesli_ilgums.doc 
[6] A. Netten, Methods Rev. 6(2), 26 (2011)

[7] L.R. Labklājības ministrija, Profesionāla sociālā darba attīstības pamatnostādnes 2014.-2020.gadam, 22-23, http://www.lm.gov.1v/upload/tiesibu_aktu_ projekti_2/iesibu_aktu_projekti_3/lmpamatn_140613_sd.pdf

[8] P. Rankin, J. Soc. Work Theory Pract. 14 (2007), https://www. bemidjistate. edu/academics/publications/social_work_journal/issue14/articles/ rankin.htm

[9] C. Simmons, P. Lehmann, Tools for Strengths-Based Assessment and Evaluation 25 (Springer Publishing Company, 2012)

[10] A. Wolk, A. Dholakia, K. Kreitz, Building a performance measurement system using data to accelerate social impact 4 (Cambridge, 2009)

[11] Н.Ю. Зубова, Качество сочиального обслуживания: Проблемы контроля качества услуг, оказываемых учреждениями сочиального обслуживания населения, http://do.teleclinica.ru/184414/

[12] Коллектив авторов, Оценка әффективности деятельности учреждений сочиальной поддержки населения; Под ред. П.В. Романова и Е.Р. Ярской- Смирновой, 38, 56,67,72,95,98,111,122 (Московский общественный научный фонд; Центр социальной политики и гендерных исследований, 2007)

[13] О.В. Логунова, С.М. Сытик, Эффективность деятельности спещиалистов сочиальной работь в условиях центра помощи семье и детям; Проблемы формирования профессионализма специалистов социальной работы: Материалы III Всероссийской научно-практической конференции 25, 26 http://www.rsvpu.ru/filedirectory/9270/zagruzheno.pdf (РГППУ, 2015)

[14] И.Н. Маяцкая, Эффективность и качество предоставляемых услуг в учреждениях сочиального обслуживания населения, Экономико-юридиbreakческий журнал Бизнес в законе 2, 232-233 (2012), http://cyber leninka.ru/article/n/effektivnost-i-kachestvo-predostavlyaemyhuslug-v-uchrezhdeniyah-sotsialnogo-obsluzhivaniya-naseleniya

[15] М. Мескон, М. Альберт, Ф. Хедоури, Основы менеджмента; 276 (Издательство “ДЕЛО”, 2004)

[16] Г.Ф. Нестерова, И.В. Астэр, Общие вопрось оценки результативности и эффективности иерковной сочиальной работы.

[17] Ю.А. Серебрякова, Аттестачия как фактор повышения әффективности труда сочиальных работников (2002), http://ref.by/refs/72/17398/ 1.html 